Review

\title{
Reviewing Value Creation in Agriculture-A Conceptual Analysis and a New Framework
}

\author{
Vera Sadovska ${ }^{1, *}$, Lena Ekelund Axelson ${ }^{1}$ and Cecilia Mark-Herbert ${ }^{2}$ (I) \\ 1 Department of Work Science, Business Economics and Environmental Psychology, Swedish University of \\ Agricultural Sciences, 23053 Alnarp, Sweden; lena.ekelund@slu.se \\ 2 Department of Forest Economics, Swedish University of Agricultural Sciences, 75007 Uppsala, Sweden; \\ cecilia.mark-herbert@slu.se \\ * Correspondence: vera.sadovska@slu.se; Tel.: +46-4041-5564
}

Received: 27 May 2020; Accepted: 17 June 2020; Published: 19 June 2020

\begin{abstract}
Creation of business value is a major objective of any enterprise, but the way in which value is created and its consequences call for re-evaluation in response to current sustainability goals. The agricultural sector serves basic human needs, but its systems and methods for production, processing, and consumption often pose challenges to sustainable development. To address these challenges, this study consolidated value-creating factors identified in a systematic literature review into nine clusters: collaboration, communication, knowledge, production, diversification, entrepreneurism, funding, policies, and inclusiveness. These clusters were analyzed with a Triple Bottom Line framework where financial, environmental, and social dimensions are part of sustainable development. The analysis revealed that agricultural enterprises pursue business activities in a near-term perspective, with few having strategies for long-term activities such as innovativeness, knowledge acquisition, and collaboration with external stakeholders. These findings highlight the complexity in creation of sustainable business value and call for further investigation of how value is conceptualized in the agricultural sector. Re-thinking value creation in the sector should consider why value is created, for whom, the time perspective in which value is assessed, and the aspects given weight in the assessment.
\end{abstract}

Keywords: added value; collaboration; communication; food production; food processing; innovation; sustainable agriculture; sustainable value; Triple Bottom Line

\section{Introduction}

Value creation plays a central role for any business system and has been referred to as "the core purpose and central process of economic exchange" [1] and "a central concept in the management and organization literature" [2] (p. 180). The traditional understanding of value in a business context links suppliers, firms, and customers, defining value as customer willingness to pay minus suppliers' opportunity costs [3-5]. In this classical view, value capture through maximization of a firm's net present value is the main objective of business activity [6-8].

While creation of business value is the major objective of any firm, the way in which value is created and its consequences require re-evaluation in response to business environment challenges [9]. With the increased importance of environmental and social factors in business, the understanding of value has expanded [10]. Views on the purpose of value creation have shifted from profit maximization to satisfying the needs of a variety of stakeholders now and in future. In other words, ideas of sustainable development have entered the business world. This process has a direct influence on the conceptualization of value and calls for closer examination. 
From another perspective, there is a gap in the understanding of context-related aspects of value creation. Value studies assume that value creation happens in the same manner irrespective of the context or the level of analysis, which provides an incomplete picture of value. Thus, there is a need for contextualized research where theoretical conclusions can be applied to a specific context, since the unique features of a context can have a substantial impact on the process of value creation, requiring exploration of meso-levels of analysis that lie between societal and organizational levels [2]. Context-specific studies of value are scarce to date, but can make fruitful contributions to the theoretical understanding of value.

The agricultural sector is one context that has not received the full attention of management research [11], despite its strategic importance worldwide. Agriculture plays a significant role in global and regional development, with the well-being and even survival of many individuals and families being dependent on efficient functioning of agricultural business systems. Therefore, exploration of value-creating activities relevant to the agricultural sector is of urgent need.

Motivated by these issues, the aim of this study was to review the conceptualization of value in agriculture and suggest a new conceptual framework for sustainable value creation. In the first step, value-creating factors in agriculture reported in the scientific literature were identified in a systematic literature review and categorized into groups. Next, the literature review findings were combined with a sustainable development perspective to produce a new conceptual framework for value creation in the agricultural sector, based on the existing sustainable value framework [12]. Areas requiring future research were then assessed.

The rest of the paper is structured as follows: Section 2 provides an overview of the value creation concept in business studies and in sustainability and agriculture perspectives. Section 3 describes the methods used for the systematic literature review and analysis of data. Section 4 presents a descriptive and content analysis of the data, while Section 5 presents the new framework for sustainable value creation in agriculture. Section 6 contains concluding remarks and suggestions for future research.

\section{Background}

The term 'value' appears in business literature with remarkable frequency, but the definitions of the term are rather vague. In product-dominated economic theory, the distinction between exchange value and use value is at the core of value discussions [13]. Exchange value refers to the change in a product in the production process, i.e., the difference between cost and sales price, while use value is a subjective perception of the value of a product or service by a customer.

The value concept has recently attracted a new wave of interest from economics and management scholars [2,14-16]. It is described as something created along the vertical chain of suppliers, firms and buyers, and dependent on the individual characteristics of chain members [17]. In this model, value is created by each member of the chain and, at the same time, each member is interested in capturing as much value as possible. How to capture value becomes the core question for an individual member of the vertical chain, and the way to achieve it is discussed in the business strategy of every firm [17]. Customer value is taken as the balance between the beneficial attributes of a product (e.g., experience, service, brand) and the price [18].

In sum, value perceptions are defined with a narrow group of stakeholders in mind, using primary financial dimensions of value. Applications to other shareholder groups, and creation of value that addresses financial, social, and environmental dimensions are not considered.

\subsection{Business Sustainability and Sustainable Value}

Firms have practiced business sustainability for many centuries. An example from 17th century Germany describes a forest management approach that accounted for the renewable capacity of the trees [19]. A more modern perspective on business sustainability can be traced back to the 1990s and publication of the Brundtland Report, which enabled businesses to set sustainable development goals in corporate context. The recognition that financial sustainability will not ensure the long-term 
prosperity of a firm made a distinction between traditional management theories and a sustainable perspective on management $[20,21]$.

The Triple Bottom Line (TBL) perspective on value creation integrates economic, environmental, and social dimensions of sustainability, and facilitates understanding of their interrelations in multiple ways [10]. TBL is currently perceived as a necessary element of strategy for any firm that aims at integrating sustainability in its business. More recent accounts of value creation present the notion of a broader stakeholder analysis where the business is a part of "creating shared value" [22].

While there is a general agreement that profitability is not a sufficient condition for long-term business success, business sustainability remains challenging. In this study, the assumption was made that firms can work to satisfy all aspects of TBL. Sustainable value implies integration of environmental, social, and financial goals into business, together with multi-stakeholder needs and long-term planning [23].

Sustainable value framework [12] is an instrument that allows value activities to be classified with the purpose of creating sustainable value. It comprises a framework that consists of four segments located along a horizontal axis "Internal-External" and a vertical axis "Today-Tomorrow" [12] (Figure 1).

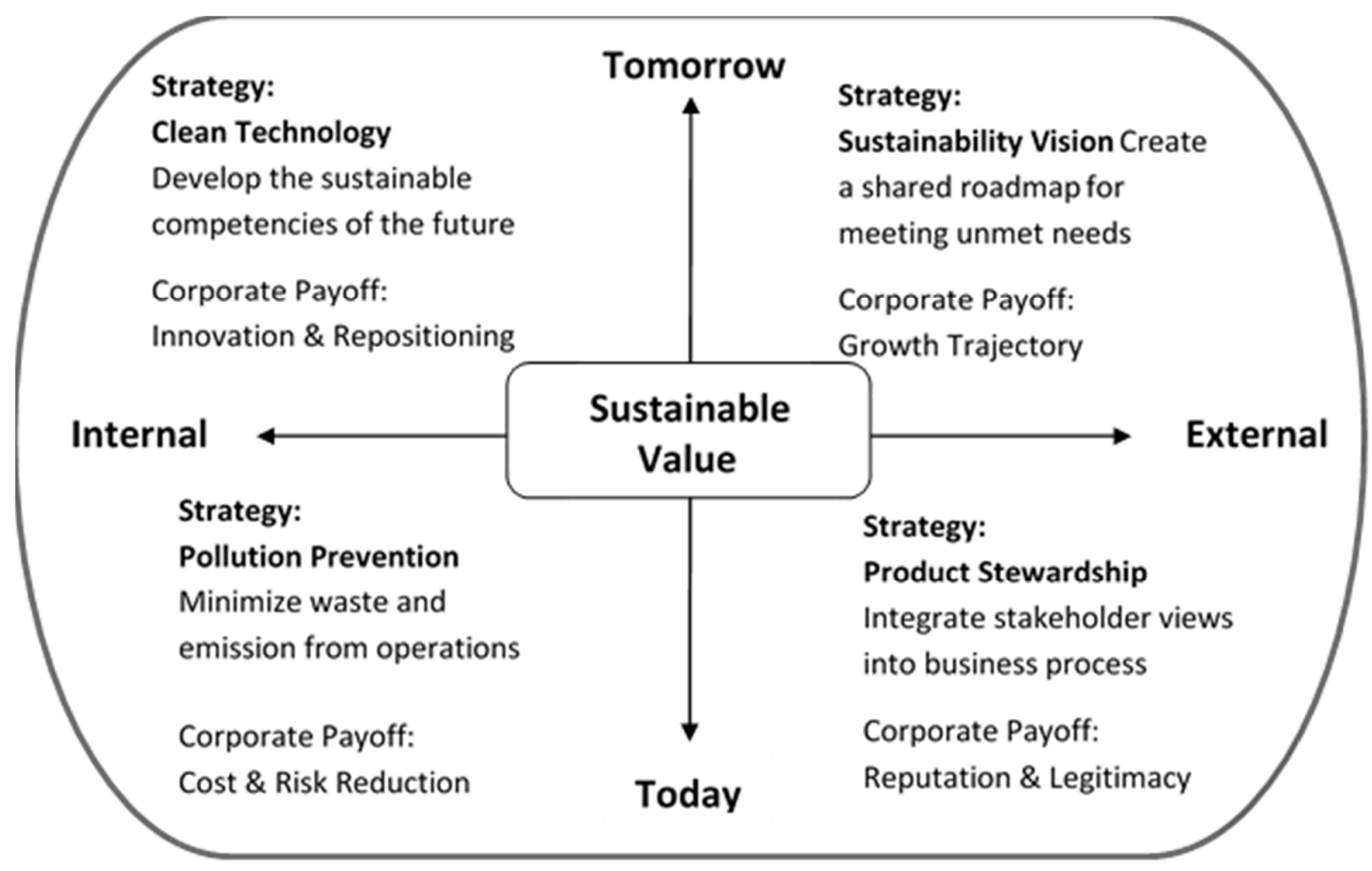

Figure 1. Sustainable value framework adapted from Hart and Milstein [12].

The framework assumes that addressing sustainability challenges is the way to achieve profitability in business while not compromising sustainability goals. By integrating activities that target pollution prevention, product stewardship, sustainability vision, and clean technology into business strategy, companies can reduce risk, improve their reputation, hasten innovations, and focus on qualitative development. In the present study, the sustainable value framework was applied to the agricultural sector to categorize value-creating activities, explain them from the point of view of sustainable development, and suggest future directions for sustainable agriculture.

\subsection{Value in Agricultural Business}

Agricultural entrepreneurship, innovation, and rural development are all intimately tied to business value creation [24,25]. Discussions about value in the agricultural literature are mostly related 
to the specific term of 'value-added agriculture'. Table 1 summarizes commonly used definitions of 'value-added' in the agricultural sector.

Table 1. Review of definitions of the value-added concept in the agricultural sector.

\begin{tabular}{ccc}
\hline Author & Definition \\
\hline Amanor-Boadu [26] & $\begin{array}{c}\text { Value-adding activity has to satisfy two conditions: (1) if one is rewarded for } \\
\text { performing any activity that has traditionally been performed at another stage } \\
\text { further down the supply chain; or (2) if one is rewarded for performing an } \\
\text { activity that is discovered to be necessary, but has never been performed in the } \\
\text { supply chain. }\end{array}$ \\
Coltrain et al. [24] & $\begin{array}{c}\text { Value-adding is economically adding value to a product by changing its current } \\
\text { place, time, and form characteristics to characteristics more preferred in the } \\
\text { marketplace. }\end{array}$ \\
\hline Ernst and Woods [27] & $\begin{array}{c}\text { Value-added agriculture" is a broad term encompassing many practices that } \\
\text { increase the value of farm products. Value-added agriculture has come to } \\
\text { describe practices as varied as agri-tourism activities that provide consumers } \\
\text { with value from visiting a farm to large-scale processing endeavors that create } \\
\text { mass-market retail food products from commodity crops. }\end{array}$ \\
\hline Lu and Dudensing [28] & $\begin{array}{c}\text { Value-added agriculture is a portfolio of agricultural practices that enable } \\
\text { farmers to align with consumer preferences for agricultural or food products } \\
\text { with form, space, time, identity, and quality characteristics that are not present } \\
\text { in conventionally-produced raw agricultural commodities. Value-added } \\
\text { agriculture can be characterized by farmers changing their position in the } \\
\text { supply chain, creating closer or direct linkages between themselves and } \\
\text { consumers, or changing production processes to alter or preserve certain } \\
\text { intrinsic characteristics of their farm/ranch products. }\end{array}$ \\
\hline
\end{tabular}

The agricultural commodity must meet one of the following five value-added methodologies:

- Has undergone a change in physical state

- Was produced in a manner that enhances the value of the agricultural commodity

- Is physically segregated in a manner that results in enhancement of the value of the agricultural commodity

USDA [29] - Is a source of farm-or ranch-based renewable energy, including E-85 fuel

- Is aggregated and marketed as a locally-produced agricultural food product

- Is a result of the change in physical state or the manner in which the agricultural commodity was produced, marketed, or segregated

The customer base for the agricultural commodity is expanded. A greater portion of the revenue derived from the marketing, processing, or physical segregation of the agricultural commodity is available to the producer of the commodity.

Value-added refers most generally to manufacturing processes that increase the value of primary agricultural commodities. Value-added agriculture may also refer to increasing the economic value of a commodity through particular

Womach [25] production processes, e.g., organic produce, or through regionally-branded products that increase consumer appeal and willingness to pay a premium over similar but undifferentiated products. 
All aspects of the value-added defined in Table 1 refer to the product as the source of value creation or a producer as the beneficiary of value. In addition, value itself is examined mostly from a financial perspective. Referring to the TBL, we see a need to view value creation based on a systems perspective, taking a broader view on sustainable agriculture.

\section{Methods}

A systematic literature review was applied in a structured evaluation of published academic work. The review objectives were to systematically access and interpret the existing body of literature and suggest areas for future development of knowledge [30,31]. With the help of a literature review, knowledge gaps can be identified, contributing to theory development [32].

The term 'value' comprises numerous meanings and is used by researchers in numerous ways. Here, the interest was in a specific understanding of value in terms of business activities in the agricultural sector, and therefore, strict selection requirements were set for the initial pool of articles. The systematic literature review performed was based on a keyword search following the PRISMA-P protocol [33] to ensure a structured and comprehensive procedure. A successful search strategy requires awareness in determining the search terms and identifying relevant papers [34]. The choices made in this study in terms of search queries are described in Table 2. Databases, Thomson Reuter's Web of Science Core Collection, and Elsevier's Scopus were used to conduct the search. The search terms consisted of "value" and its derivatives, together with "agriculture" or "farming" or "horticulture". The document type was "article", language "English", and subject areas limited to business or management. The search was based on titles, abstracts, and keywords.

Table 2. Databases and terms used in the search queries in this study, and number of hits obtained.

\begin{tabular}{|c|c|c|}
\hline Database & Search Query & No. of Results \\
\hline Scopus & $\begin{array}{l}\text { TITLE-ABS-KEY (agro* OR agri* OR farm* OR } \\
\left.\left.\text { agrar* OR horti*) AND TITLE-ABS-KEY ( ( }^{*} \text { value W/2 creat* }\right) \text { OR ( value W/2 captur* }\right) \text { ) }\end{array}$ & 135 \\
\hline Web of Science Core Collection & $\begin{array}{c}\mathrm{TS}=\left(\text { value near } / 2 \text { creat }^{*}\right) \text { or }(\text { value near } / 2 \\
\text { captur }) \text { AND TS }=\left(\text { agro }^{*} \text { or agri* or farm* or }\right. \\
\left.\text { agrar* or horti }{ }^{*}\right)\end{array}$ & 61 \\
\hline
\end{tabular}

Boolean modifier the asterisk, ${ }^{*}$, searches for any word that begins with the stem of the word truncated by it.

The limitations of pre-defined search terms are that only articles that use the same vocabulary can be retrieved. The search terms used here were taken from the business administration literature, so articles in other disciplines that use different terms to describe the same concept would not appear in the search. By applying filters and after elimination of duplicates in the original database of 196 articles (135 from Scopus together with 61 from Web of Science), the remaining 173 articles were assessed manually by reading the title and abstract. The procedure is described in Figure 2.

Following the procedure, the original database was reduced to 121 articles, which were analyzed in depth by assessing the full text. Finally, the list was reduced by 13 articles to form the final set of 108 articles. The inclusion criterion were that an article should have any kind of agriculture or food production as the main topic. The exclusion criterion excluded articles where agriculture was not the main focus; articles not written from a business perspective; and articles not reporting added value as a result of certain activities. 


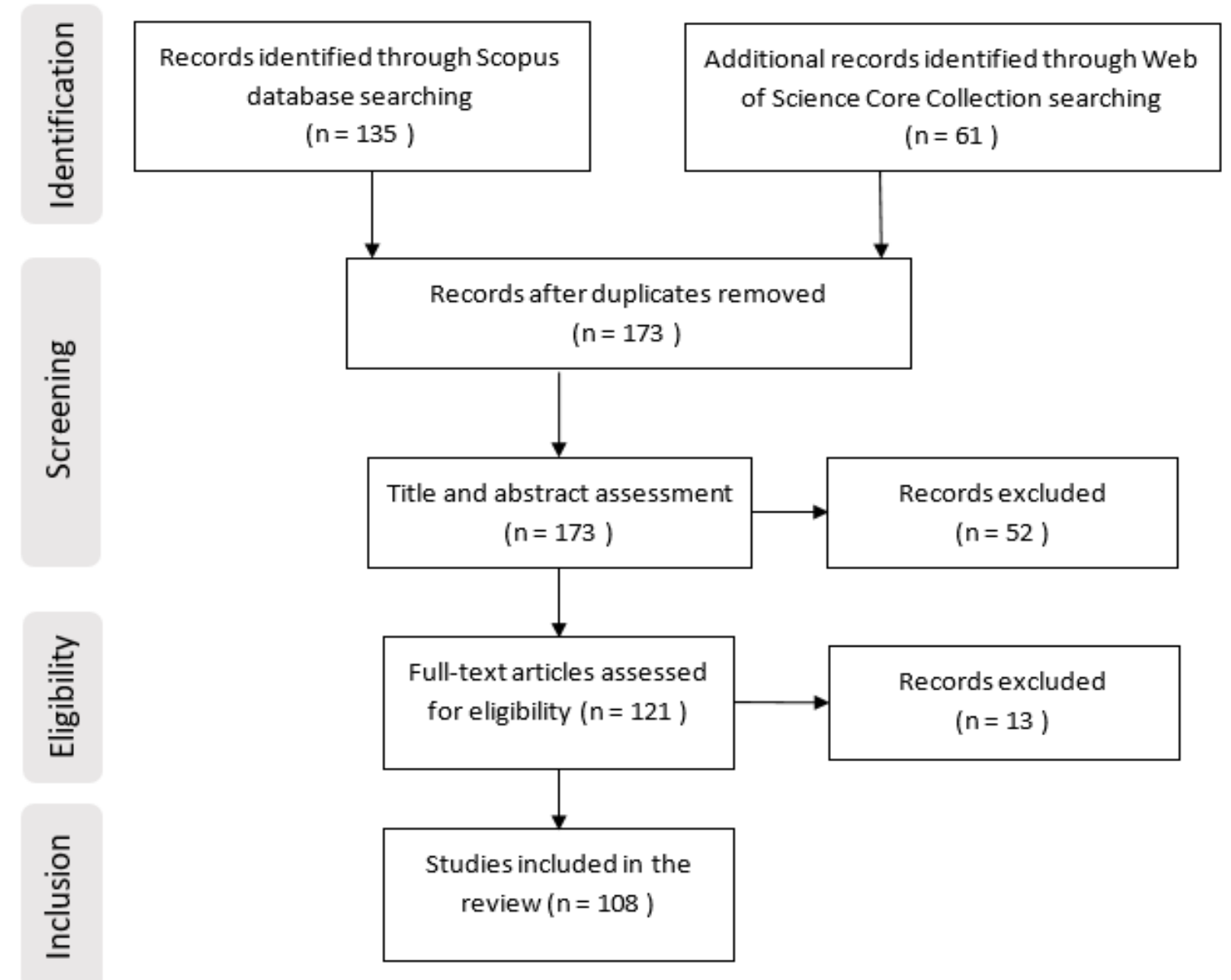

Figure 2. PRISMA 2009 flow diagram of stages followed in the systematic literature review.

In the next stage, descriptive and content analysis was performed to identify the value-creating factors in the selected papers. This is done by the process of reducing the textual data by theme identification and frequency analysis [35]. Due to the broadness of the value concept, different terms in the literature are sometimes used to represent similar value-creating activities. With the help of the content analysis, it was possible to consolidate these activities into clusters based on relevance, providing a more concise classification of results.

\section{Results}

The papers reviewed applied a variety of methodological approaches to data collection and analysis. About half involved case studies, some of which were longitudinal [36,37]. Others used survey data [38,39], and a small proportion of articles employed observation and participatory methods [40,41]. Data analysis methods included statistical methods, economic modeling, and a meta-analysis [42]. Figure 3 shows the trend in publication numbers over the period 1995-2018. 


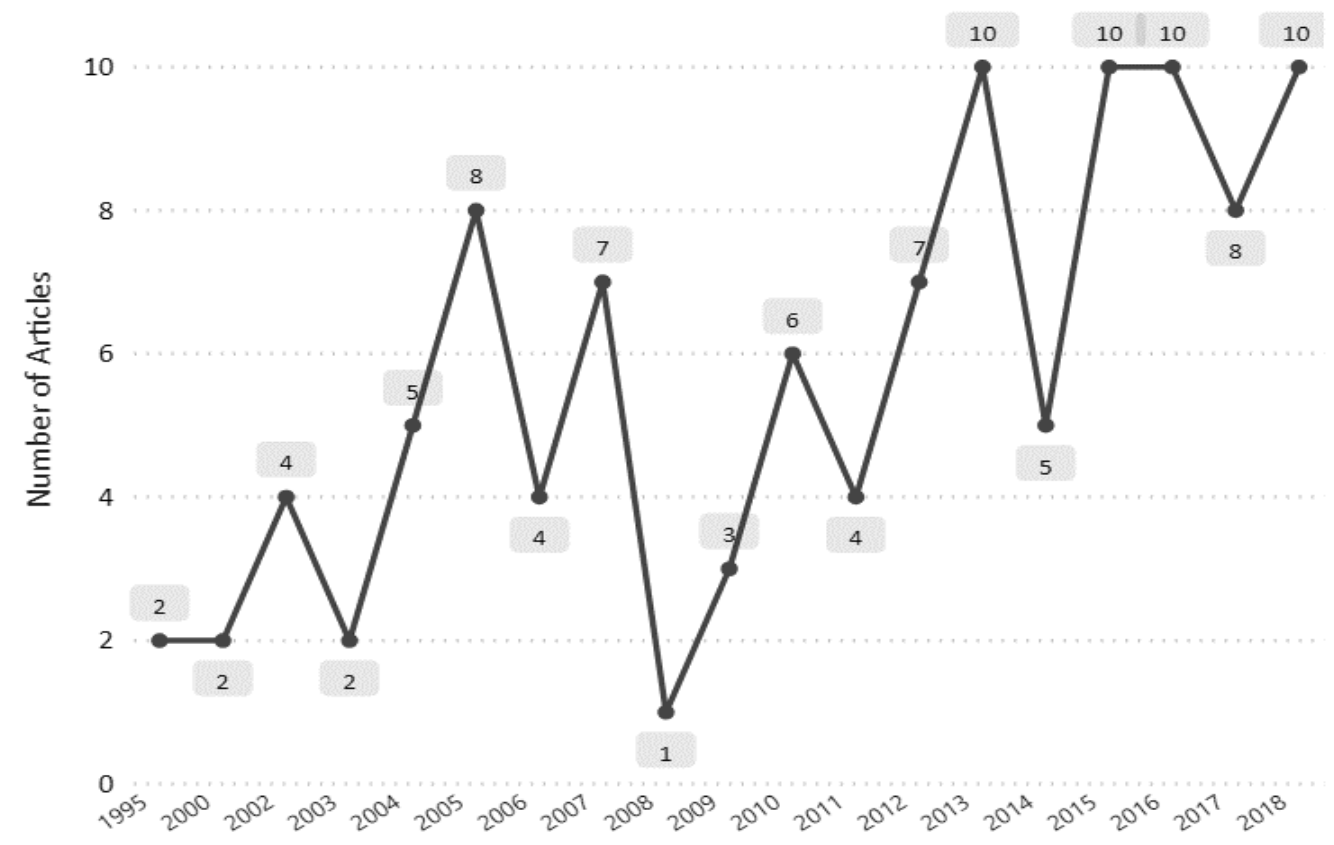

Figure 3. Number of publications on value creation in agriculture produced annually in the period 1995-2018.

Although the database search had an open start date, the oldest retrieved publication was dated 1995. The explanation might be that other terms to describe the concept were used earlier (e.g., "value addition" instead of "value creation"). There was a clear increase in the number of publications over time (Figure 3).

\subsection{Content Analysis}

Analysis of the articles enabled identification of 23 distinct value-creating factors mentioned in the literature (Figure 4). The order in which factors are listed in the figure corresponds to the frequency of indications in articles (i.e., factor 1 on the list was mentioned most often).

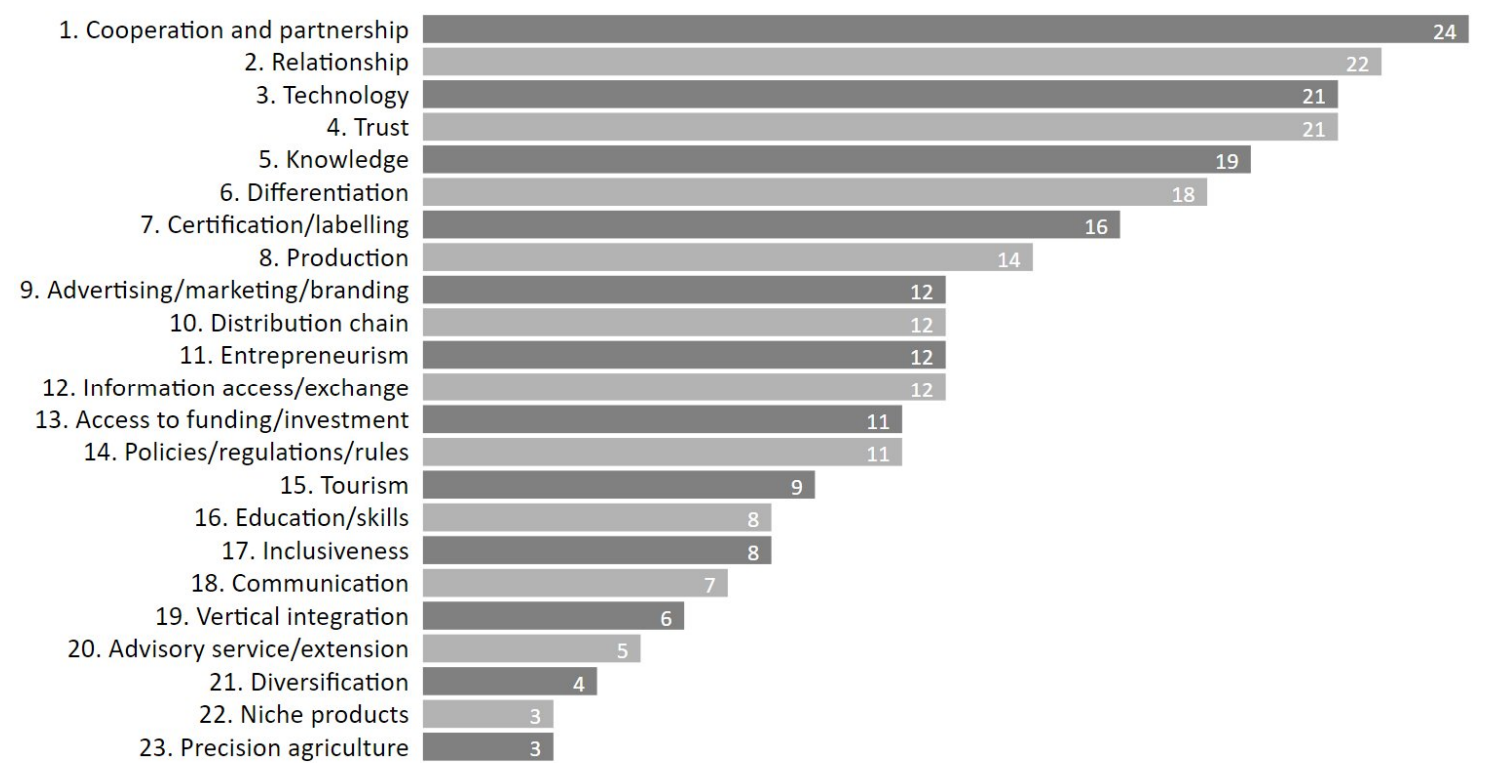

Figure 4. Value-creating factors (23) mentioned in the set of 108 articles reviewed. Number of mentions of factors indicated on bars. 
In total, 278 indications of different value-creating factors were found in the sample of 108 articles. Figure 5 presents the papers with the indication of the factors mentioned in these 108 articles.

\begin{tabular}{|c|c|c|c|}
\hline No & Sources & Year & Factors \\
\hline 1 & Anic and Nusinovic [43] & 2005 & $3,8,13,14$ \\
\hline 2 & Armstrong et al. [39] & 2005 & $6,9,18$ \\
\hline 3 & Atănăsoaie [44] & 2011 & $2,6,10$ \\
\hline 4 & Austin and Leonard [45] & 2008 & $1,17,18$ \\
\hline 5 & Badar et al. [46] & 2015 & 7,9 \\
\hline 6 & Baron, 2011 [47] & 2011 & 4,6 \\
\hline 7 & Batterink et al. [48] & 2010 & $1,13,20$ \\
\hline 8 & Bertazzoli et al. [49] & 2011 & 1,10 \\
\hline 9 & Bogale et al. [51] & 2018 & $8,9,10$ \\
\hline 10 & Boehlje [50] & 2004 & 3,8 \\
\hline 11 & Boland [52] & 2003 & 3 \\
\hline 12 & \begin{tabular}{|l} 
Bongiovanni and Lowenberg- \\
Deboer [53]
\end{tabular} & 2004 & $3,5,23$ \\
\hline 13 & Bonney et al. [54] & 2013 & 11,17 \\
\hline 14 & Briscoe and Ward [56] & 2006 & $1,11,21$ \\
\hline 15 & Bramley and Kirsten [55] & 2007 & 6,7 \\
\hline 16 & Bryla [57] & 2017 & 7,10 \\
\hline 17 & Campbell and Doherty [58] & 2013 & 5,22 \\
\hline 18 & Carriquiry and Babcock [59] & 2007 & 4,7 \\
\hline 19 & Che [60] & 2006 & $9,15,21$ \\
\hline 20 & Chen and Tang [61] & 2015 & 12,23 \\
\hline 21 & Chumaidiyah [62] & 2017 & 6,8 \\
\hline 22 & Cloesen [63] & 2007 & $11,15,21$ \\
\hline 23 & Cucagna and Golds mith [64] & 2018 & $2,6,8$ \\
\hline 24 & Darroch et al. [65] & 2002 & 2,6 \\
\hline 25 & Dentoni et al. [66] & 2012 & 2,18 \\
\hline 26 & de Carvalho and Mendes [67] & 2016 & 8,10 \\
\hline 27 & Declerck and Cloutier [68] & 2010 & 3,7 \\
\hline 28 & Deselnicu et al. [42] & 2013 & 7 \\
\hline 29 & Dey et al. [69] & 2016 & $3,5,15,16,17,18$ \\
\hline 30 & Di Gregorio [70] & 2017 & $6,11,15$ \\
\hline 31 & Duffy and Fearne [71] & 2004 & 1,2 \\
\hline 32 & Eastwood et al. [36] & 2012 & $2,3,5,20$ \\
\hline 33 & Fafchamps and Minten [72] & 2002 & 2,12 \\
\hline 34 & Ferrazet al. [73] & 2018 & $4,5,18$ \\
\hline 35 & Giannakis and Bruggeman [74] & 2015 & $5,13,14$ \\
\hline 36 & Gloy and Akridge [75] & 2000 & 3,5 \\
\hline 37 & Grayet al. [76] & 2004 & 5,13 \\
\hline 38 & Goldsmith and Bender [77] & 2004 & $2,6,12$ \\
\hline 39 & Goldsmith and Gow [78] & 2005 & 6,19 \\
\hline 40 & Grunert et al. [79] & 2005 & $2,9,12,14$ \\
\hline 41 & Hall [80] & 2005 & 3 \\
\hline 42 & Hsuet al. [81] & 2013 & 1,15 \\
\hline 43 & Han and Chuang [82] & 2015 & $1,4,16,17$ \\
\hline 44 & Handayati et al. [83] & 2015 & $1,10,18$ \\
\hline 45 & Hartlieb and Jones [84] & 2009 & 4,7 \\
\hline 46 & Hastings et al. [85] & 2016 & $2,4,10$ \\
\hline 47 & Higgins and Laredo [40] & 2006 & 5,12 \\
\hline 48 & Hinrichs [86] & 2000 & 2,10 \\
\hline 49 & Hinterhuber [87] & 2002 & 1,20 \\
\hline 50 & Howieson et al. [88] & 2016 & $1,2,3$ \\
\hline 51 & Hunt et al. [89] & 2012 & $2,4,9$ \\
\hline 52 & Jayashankar et al., (A) [90] & 2018 & 3,4 \\
\hline 53 & Jayashankar et al., (B) [91] & 2018 & 3,4 \\
\hline 54 & Jraisat [92] & 2016 & $1,10,17$ \\
\hline
\end{tabular}

\begin{tabular}{|c|c|c|c|}
\hline No & Sources & Year & Factors \\
\hline 55 & Jolink and Niesten [93] & 2015 & $6,7,11$ \\
\hline 56 & Kaaristo [94] & 2014 & 11,15 \\
\hline 57 & Kastelli et al. [95] & 2018 & 3,14 \\
\hline 58 & Katz and Boland [96] & 2002 & $1,8,12,22$ \\
\hline 59 & Kline et al. [97] & 2017 & $4,6,15,16,22$ \\
\hline 60 & Leguizamon et al. [98] & 2016 & $1,2,6$ \\
\hline 61 & Liang [99] & 2017 & $5,11,15$ \\
\hline 62 & London et al. [100] & 2010 & 4,13 \\
\hline 63 & Lutkemeyer Filho et al. [101] & 2015 & $2,4,20$ \\
\hline 64 & Marotta et al. [102] & 2017 & 2,4 \\
\hline 65 & Matopoulus et al. [103] & 2007 & 1 \\
\hline 66 & McBratney et al. [104] & 2005 & $3,5,23$ \\
\hline 67 & Melton and Huffman [105] & 1995 & 3,19 \\
\hline 68 & Mishra et al. [106] & 2009 & $8,13,16$ \\
\hline 69 & Moeen and Agarwal [107] & 2017 & 3,5 \\
\hline 70 & Menozzi [108] & 2014 & $5,7,12,14$ \\
\hline 71 & Meissner and Komba [109] & 2012 & $4,6,11,19$ \\
\hline 72 & MK Leat and Revoredo-Giha [110] & 2013 & $1,4,6,7$ \\
\hline 73 & Migliore et al. [111] & 2015 & 9,10 \\
\hline 74 & Micheels and Gow [112] & 2009 & $3,4,5,6,8$ \\
\hline 75 & Montealegre et al. [113] & 2007 & 3 \\
\hline 76 & Moulton and Zwane [114] & 2005 & 1,14 \\
\hline 77 & Munjal et al. [115] & 2016 & $4,6,7,15,19$ \\
\hline 78 & Neganova [116] & 2010 & 9,16 \\
\hline 79 & Nettle et al. [37] & 2013 & 12,20 \\
\hline 80 & Pannekoek et al. [117] & 2005 & $1,11,18$ \\
\hline 81 & Pant et al. [118] & 2012 & $8,16,17$ \\
\hline 82 & Pascucci and Magistris [119] & 2013 & 5,12 \\
\hline 83 & Patel [120] & 2014 & 1,10 \\
\hline 84 & Pennings [121] & 2010 & 9,13 \\
\hline 85 & Peterson [122] & 2013 & $1,3,5$ \\
\hline 86 & Polo Redondo and Cambra Fierro [123 & 2007 & 2,4 \\
\hline 87 & Poniman et al. [124] & 2015 & $1,4,7$ \\
\hline 88 & Ramesh [125] & 2010 & $2,11,17$ \\
\hline 89 & Ruslan et al. [126] & 2013 & $5,8,9,13,14$ \\
\hline 90 & Safri [127] & 2015 & 11,17 \\
\hline 91 & Shah and Ghazzawi [128] & 2012 & 8,21 \\
\hline 92 & Semenda et al. [129] & 2018 & 14 \\
\hline 93 & Sexton et al. [130] & 2007 & 19 \\
\hline 94 & Shieh and $\mathrm{Hu}[131]$ & 2016 & $1,5,16$ \\
\hline 95 & Sturaro et al. [132] & 2013 & $7,8,14$ \\
\hline 96 & Sturiale and Scuderi [133] & 2016 & 3,12 \\
\hline 97 & Sogn-Grundvag et al. [41] & 2014 & 7 \\
\hline 98 & Starr et al. [134] & 2003 & 9,10 \\
\hline 99 & Tampe [135] & 2018 & $2,7,19$ \\
\hline 100 & Tang et al. [136] & 2016 & $1,2,4$ \\
\hline 101 & Teklehaimanot et al. [137] & 2017 & $5,12,16$ \\
\hline 102 & Tencati and Zsolnai [138] & 2012 & $1,4,8$ \\
\hline 103 & Thilmany et al. [38] & 2006 & 7 \\
\hline 104 & Thomas-Francois et al. [139] & 2018 & 2,11 \\
\hline 105 & Tzouramani et al. [140] & 2011 & $6,13,14$ \\
\hline 106 & Uzea and Fulton [141] & 2014 & $1,2,9$ \\
\hline 107 & Woiceshyn [142] & 1995 & $3,12,13$ \\
\hline 108 & Zavorotin et al. [143] & 2018 & 13,14 \\
\hline
\end{tabular}

Figure 5. Papers in which value-creating factors 1-23 were mentioned [43-143].

Analysis of the frequency of mention of different terms revealed that cooperation and partnership factor occurred most often in the literature, mentioned in 24 of 108 sources, followed by relationship (22/108) and technology (21/108) (Figure 5). The least frequently mentioned factors were niche products and precision agriculture (both 3/108) (Figure 5). Frequency of mention does not necessarily reflect the 
significance of a factor, since it can be affected by the time at which a factor first appears in the literature. Thus, the present frequency analysis did not reveal the importance of certain factors over others, but showed that some factors are more commonly discussed in the agricultural business community.

Some of the 23 factors refer to similar contexts or closely related concepts. To improve the accuracy of results and efficiency of analysis, the number of variables had to be reduced [144]. Therefore, the value-creating factors were analyzed based on thematic similarity and similar concepts were united into clusters. Following this, the 23 factors were consolidated into 9 clusters (Figure 6): collaboration, communication, diversification, knowledge, production, entrepreneurism, funding, inclusiveness, and policies. Although some factors were interconnected and could be assigned to several clusters, they were placed in the most relevant cluster. Each cluster is further described in Sections 4.1.1-4.1.9.

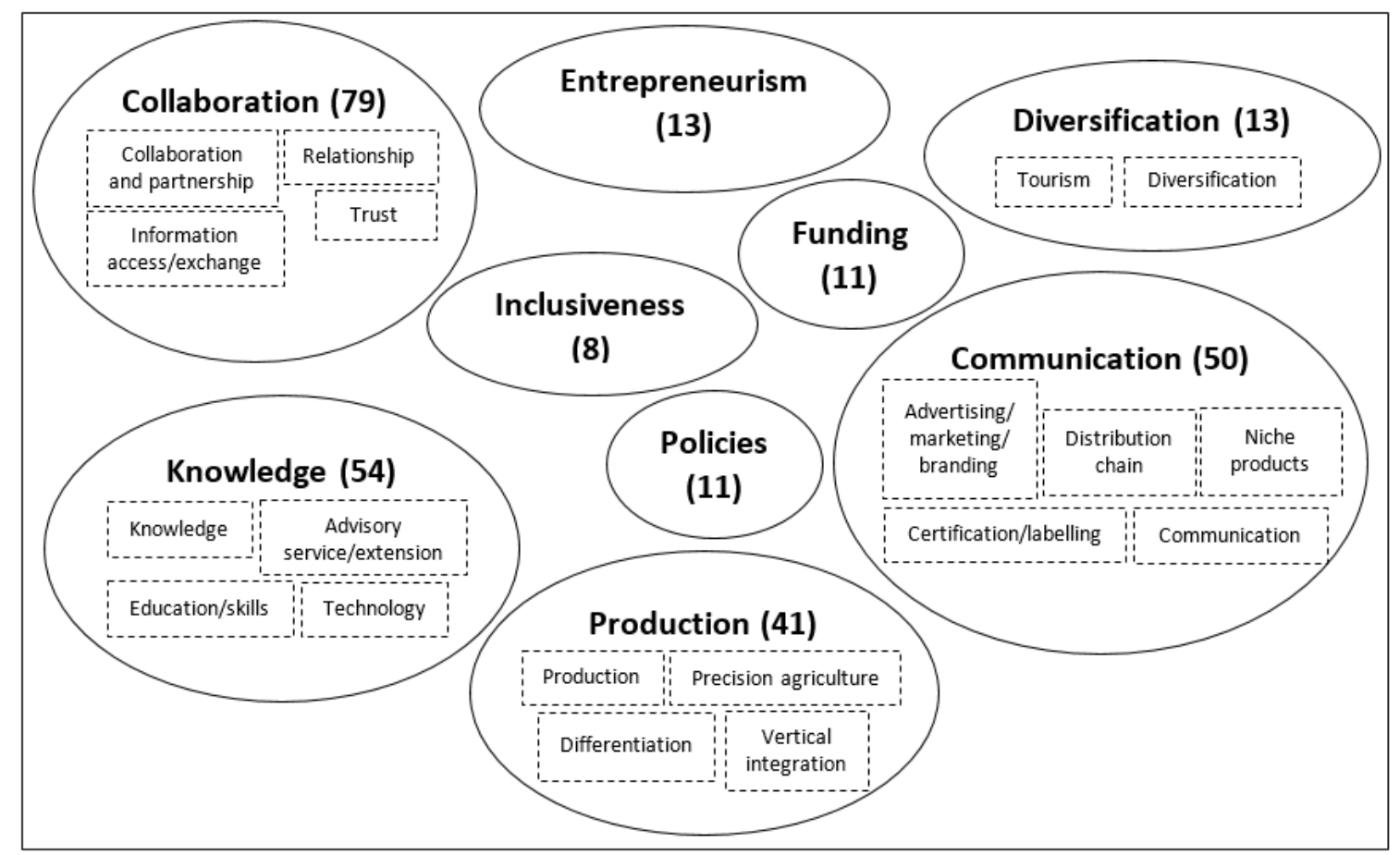

Figure 6. Nine clusters of value-creating factors identified in the agricultural business literature (number of mentions of component factors in brackets).

\subsubsection{Collaboration}

The collaboration cluster included all kinds of partnerships and relationships in agricultural enterprises. It also encompassed topics such as trust and information access. Collaboration occurs at all levels of the value chain, with practical examples being knowledge exchange, common use of processing, testing, and R\&D facilities, etc. Collaboration also appears in the form of farmers' federations and established joint ventures. Formal organizations can act as promoters of certain trends such as encouraging organic production, certification of products or development of new sales channels, and joint purchasing of inputs. In the example of dairy cooperatives in Ireland, collaboration with outsourcing partners is used to optimize business activities [56]. Small-scale cooperatives cooperate in collective use of testing, processing, and storage facilities [85]. This allows farmers to avoid investments in higher capacity facilities. Farmers also collaborate informally on EU milk quotas by transferring quotas between cooperatives.

\subsubsection{Diversification}

According to the literature reviewed here, farmers can achieve financial sustainability in their business and increase their own well-being through diversification. The articles mentioned agriculture- 
or non-agriculture-related diversification. Examples of agriculture-related diversifying activities are growing vegetables for sale by dairy farmers [56] and production of feed for sale by meat farmers. Examples of non-agriculture diversification are selling or lending land to another business, building non-agricultural facilities on own land [139], and opening (eco-) tourism on the farm [63,94]. Establishing a rural tourism venue was a commonly suggested way to diversify the agricultural business, as it can provide additional income [63], lead to the purchase of agricultural products [99], and also stimulate rural development [81] and protect environmental resources [139].

\subsubsection{Communication}

Communication refers to the way in which a company presents itself to clients, partners, and employees. An agricultural company communicates through its marketing strategy and the identity of its products. Product identity relates to activities such as certification, labeling, and branding. Certification and labeling are closely related and certification often leads to a label on a product. The purpose of certification is to ensure the safety and traceability of agricultural products from producer to consumer, which enhances consumer confidence and trust, and enables the creation of value-creating services for a producer. One study [58] reported a link between certification and economic benefits for the producer. The motivation behind labeling has two sides, economic and idealistic [84]. Evidence suggests that customers are attracted by different claims made by labels, such as "no antibiotics", "no hormones", or "humane treatment" [38]. In one study, almost 65\% of survey respondents were ready to pay a price premium for health benefits offered by health-enhancing dairy products [39]. Labeling schemes such as Geographic Indicators have led to price premiums, though the level varies for different categories of products [42].

Communication with partners along the distribution chain plays an important role for the business. The distribution chain comprises: direct (sales direct from the farm), short-distance (including farmers' markets, specialist organic stores, home delivery, restaurants), and traditional (deliveries to supermarkets or wholesalers, or through cooperatives). [44]. Direct and short-distance supply chains are associated with a positive effect on the local economy and increased trust among consumers [111]. In addition, a short distribution chain provides the possibility to obtain a price premium in niche markets [134].

\subsubsection{Knowledge}

Agricultural knowledge is embodied in multiple activities of an agricultural enterprise, including the emergence of new technologies for products or processes $[80,118]$. Education and the development of skills, together with knowledge transfer through advisory services, emerged as topics throughout the literature reviewed. An assessment of the economic performance of the agricultural sector in $27 \mathrm{EU}$ member states demonstrated that a better educated and trained farm population achieved almost nine-fold better economic performance [74]. A written business plan, a higher number of decision-makers, and engagement in value-added agriculture were reported to have a positive effect on the financial performance of new farm businesses [106]. Decision support systems (DSS) can be used to automatize farm tasks and manage large, complex businesses in order to improve control and optimize farm performance [36]. According to the study, core competencies necessary for successful implementation of DSS are:

- Information technology skills - a farmer requires at least a basic understanding of IT

- Engagement-farmers should actively engage with the system, e.g., in order to see new opportunities that individual animal data can provide

- Knowledge exchange-information about the system should flow between users and system database

The program team approach enables communication and knowledge sharing between groups of researchers, public and private organizations, farmers, the community, extension services, policy 
makers, and service groups [37]. Extension services from an innovation broker bring value for development of innovation networks. With the support of a broker, a farm gains access to knowledge at the inter-organizational level [48].

\subsubsection{Production}

The value-creating factors incorporated in the production cluster were mentioned in 41 articles (Figure 5). They included different production techniques (e.g., precision agriculture), differentiation strategies, and a general indication of the importance of production efficiency for value creation. Creating value in production brings higher returns on investment. Labor optimization through a decrease in the number of harvesting groups and increase in the hours per machine brings a net cost reduction [40].

Precision agriculture is a way to create economic and environmental value [145]. It allows chemicals to be used more efficiently, providing cost minimization and environmental protection [53]. However, for precision agriculture to advance, it requires development of DSS [104].

The literature reviewed highlighted the importance of vertical integration of smallholders to processing firms. A study of the beef and pork industry in the USA [105] noted that top-down vertical integration is an important factor for the success of producers. Moreover, vertical integration into food processing and further down the value chain can capture a larger share of "food dollars" by agricultural enterprises [130].

\subsubsection{Funding}

Access to funding and investments is crucial for development of agricultural enterprises, as the capital intensity of the sector requires major initial financial inputs. Low-cost and safe financing sources stimulate innovativeness and increase knowledge adsorptive capacity in the sector [48]. Government support is important because of the high level of risks [126]. The competitiveness of the sector is constrained in the absence of government funding and unfavorable conditions for acquiring funding from other sources, like commercial banks. Access to working and intellectual capital depends on affordable and low-risk credit [100]. Consequently, countries that invest in their agricultural sector and create a favorable financial environment tend to have high-performing and competitive agricultural businesses [74] that are able to overcome constraints with the help of investments [100].

\subsubsection{Policies}

Policies appeared in 11 articles as a factor contributing to value creation. Policies usually have influence beyond an individual agricultural enterprise, affecting the whole sector locally or internationally. In the European context, some farmers have stayed in business thanks to the income support payments provided under the EU common agricultural policy, which also aims to improve quality of life in rural areas [74]. A study on the apple processing industry showed that government engagement in a transparent agricultural policy has had a positive effect on infrastructure, technology, and cooperative arrangements [43]. Special policies targeting Geographic Indicators (GI) can promote long-term economic success and rural development by creation of favorable conditions for GI-marked products [108]. In addition, the market orientation of agricultural producers and the whole value chain can be enhanced by corresponding regulations [79]. Aside from formal regulations, voluntary agreements provide support for policy implementation. By stimulating interest groups in the industry, the government manages risk better, and with lower costs [114]. 


\subsubsection{Entrepreneurism}

Entrepreneurism in the agricultural sector refers to the opportunities to "create a more efficient and effective agricultural system" [54] (p. 2) by using resources in creative ways. Large corporations often limit the choices of smaller actors in the sector. In contrast, a high level of entrepreneurism is linked to the financial success of small players, along with their ability to compete with larger enterprises [56]. Agricultural entrepreneurs also create value as mediators between the environment and customers in the area of rural tourism [94], and in the main agricultural business activities [93]. The image of local embeddedness created by entrepreneurs in relation to their business is reported to be another source of value creation [70].

\subsubsection{Inclusiveness}

Inclusiveness in the agricultural business means consideration of the interests of smallholders, large commercial business entities, communities, and society as a whole. In the literature reviewed here, inclusiveness was often studied in relation to the low-income context, aiming to create value and empower local communities and small agricultural enterprises. The presence of cooperation and partnership is reported to be a prerequisite for inclusiveness $[118,131]$. Creation of value can be achieved by different aspects of inclusiveness. Local embeddedness of an enterprise contributes to long-term value creation for the benefit of multiple stakeholders by lowering adaptation costs [82]. Inclusive networks of agricultural enterprises have a positive impact on business performance [92]. In the African context, inclusive supply chains led to transformation of smallholders into commercially-oriented enterprises enhancing rural development and improving food security in the region [137].

\section{A New Framework for Sustainable Value Creation in Agriculture}

The value-creating business activities identified in the agricultural sector literature review were associated in different papers with organizational aspects (collaboration, inclusiveness, funding), concept orientation (diversification), marketing (communication), macroenvironment (policies), skills (knowledge and entrepreneurism) and technology (production) (Figure 6). This section builds on existing activities to move towards sustainable value creation and to re-think it in light of long-term perspective and circularity.

\section{Re-thinking Value Creation}

The new framework for sustainable value creation in agriculture builds on the nine clusters of value-creating factors previously identified in the agricultural business literature. To take a step further, these previously identified clusters are interpreted from a sustainability perspective. Specifically, what was earlier perceived as a one-dimensional value creating activity (e.g., production) is translated into Triple Bottom Line value where environmental and social dimensions are as important as the financial dimension. Moreover, the new framework incorporates additional concepts that specifically target the sustainability of the sector (Figure 7). The choice of the additional concepts is partly guided by Hart and Milstein [12] in combination with very recent studies [146-150] and the authors' own experience. This integration of earlier identified and new concepts aims to connect value and sustainability in agriculture. 


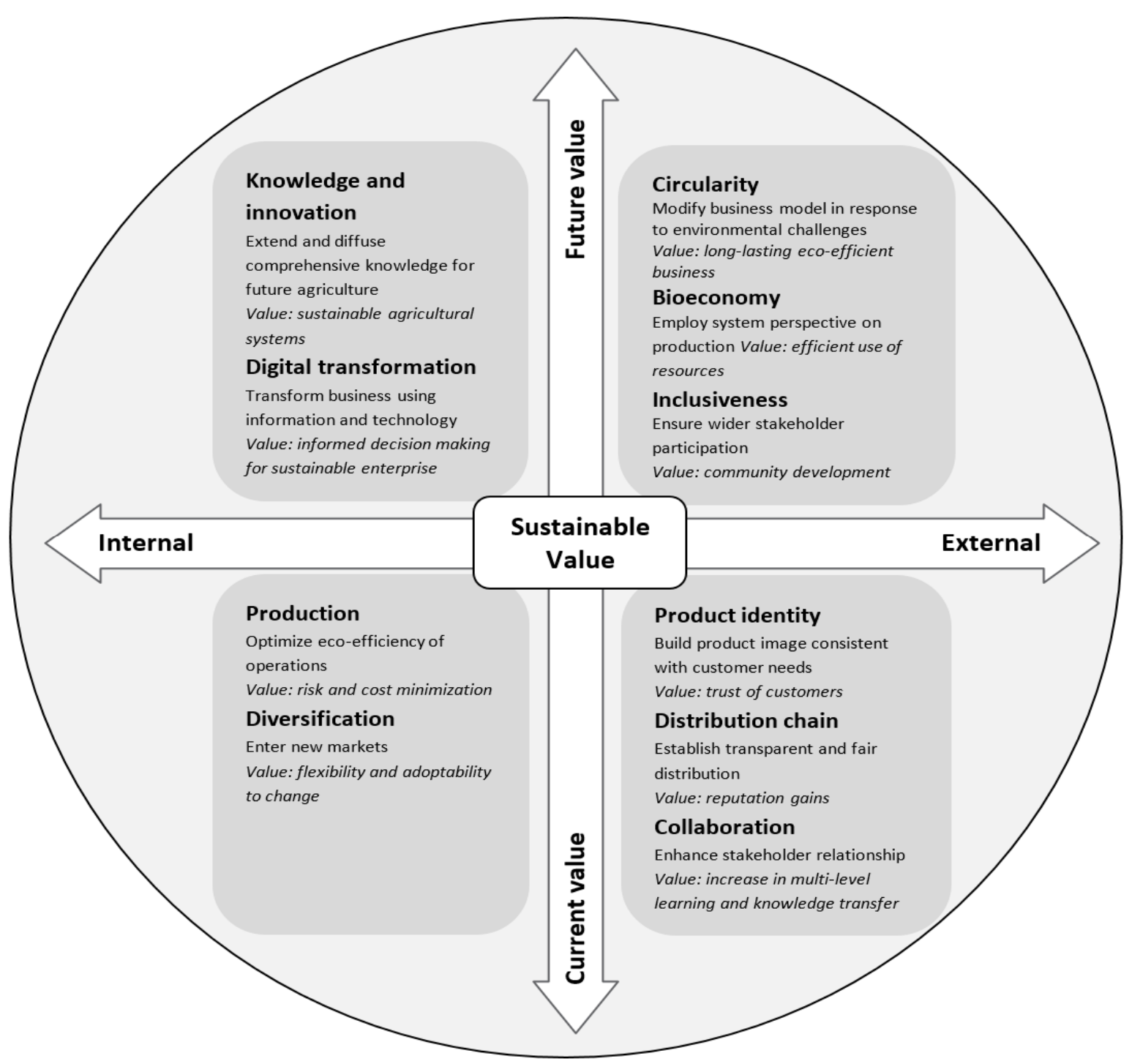

Figure 7. New framework for sustainable value creation in the agricultural sector.

In the new framework for the agricultural sector, the vertical axis "Current value-Future value" represents the connection between activities addressing value of today and perspectives for the future value. The horizontal axis "Internal-External" reflects the need to maintain internal value activities and interactions with the external surroundings simultaneously.

The lower-left segment of the framework encompasses production and diversification, both activities conducted internally inside the organization. They focus on managing current business resources allowing for cost reduction and risk minimization. These types of activities are common for the agricultural sector and a large number of scientific articles provide proof of their successful application in business. The new framework suggests extending the understanding of efficient production by including environmental and social impacts as an inherent part of efficient production. A relationship between farm value and climate change has been reported, where more land will become unsuitable for farming after the climate warms above the certain temperature [151]. Thus, accounting for environmental impact provides grounds for risk management and cost minimization in conditions of uncertainty due to global environmental challenges. The social side of risk minimization includes increased work safety and resilient livelihood of the rural population [152,153]. Therefore, a sustainable value of risk and cost minimization is not only limited to financial gains for the producer, but also comprises mitigation of environmental damage and improved social conditions. Besides, 
value is intimately connected to the context in which production and consumption take place. In the eyes of the consumer, value may include environmental impact of a product, social standards of production, price, etc. Hence, by perceiving risk in a sustainable value perspective, producers can meet broader consumer interests.

In contrast to the traditional value of diversification (more opportunities for financial returns), the new framework calls for a broader understanding of diversification that aims for socioeconomic efficiency and community development. This resonates with eco-efficient production, as it results in flexible and adaptable business entities more prepared for changes arising in environmental and social domains.

In the existing sustainable value framework (Figure 1), the lower-right segment includes a product stewardship strategy, which is achieved by integrating external stakeholders' opinions. The new framework develops and contextualizes the original idea by suggesting integration of additional elements into this segment. Product identity, distribution chain, and collaboration activities take place in this segment of the framework. They are related to external stakeholders of a firm (e.g., suppliers, customers, and media) and are associated with the short-term business horizon. By working with product identity, agricultural enterprises interact with customers to recognize their needs and gain trust by creating socially and environmentally safe and reliable products. The TBL perspective on the distribution chain targets integration of transparency and fairness into all links of a chain, and promotes transformation from linear distribution to an interconnected network of partners. Fulfilment of these conditions results in value gains of a steady and solid reputation reflected in products and corporate branding. Facilitating collaboration is a new path for sustainable value creation [12]. The articles reviewed here gave examples of collaborations between agricultural enterprises with the purpose of joint use of production facilities, storage space, or conducting R\&D activities. The articles did not provide evidence of explicit inclusive dialog between firms and stakeholders. Thus, although collaboration exists in the sector, it is unclear how organizational arrangements influence sustainable development. The view on collaboration expressed in the new framework points to the need for enhancing relationships with stakeholders. By consolidating collaborations, an agricultural enterprise can complement its knowledge on multiple levels and convey this knowledge further.

The top level of the new framework consists of activities that are oriented to the future value horizon. The upper-left segment in the new framework encompasses knowledge and innovations together with digital transformation. The importance of disruptive innovations in the agricultural value chain have been emphasized in the literature [154]. This corresponds to the statement that creation of value for a firm is dependent on its ability to "creatively destroy its current capabilities in favor of the innovations of tomorrow" [12]. Between the dimensions 'Internal' and 'Future value' in the new framework, knowledge and innovation activities take a prominent position and are considered not only as a source of value, but also as a prerequisite for value-creating activities in other dimensions of the framework. Problems with knowledge transfer are among the reasons for slow progress with the environmental dimension of sustainability [155]. As agricultural production interacts with the environment, knowledge of ecosystems management promises to be beneficial for the future of the sector. Efficient production and environmental balance can be achieved by having knowledge of ecosystems [156]. Further knowledge spread through education has a positive impact on innovativeness [157]. While innovativeness stimulates business performance [158], in the context of sustainable value, innovations should strive for solutions in environmental and social domains. Digital transformation is interconnected with knowledge and innovation, as it implies business transformation based on information and technology which results in informed decisions for the responsible enterprise.

Circularity, bioeconomy, and inclusiveness are value-creating activities in the upper-right segment of the new framework. Agricultural value creation has been discussed historically in terms of supply chains and value chains with linear understandings. Future needs for sustainable food systems call for new models that are circular and connect resources between production and consumption. The TBL perspective may offer grounds for understanding all three dimensions of value, which in turn calls 
for new business models [159]. These perspectives replace the end-of-life concepts with restoration, assume collaboration and knowledge, and put emphasis on smart design. The new framework develops the original idea of this dimension (sustainability vision) by suggesting bioeconomy as a vision for agriculture. Bioeconomy emerged as a response to global environmental challenges. It aims at the systemic transformation of manufacturing by promoting renewable resources [160]. Bioeconomy perspective adopted by an agricultural enterprise enables the creation of long-term value for people and the planet.

Inclusiveness as a suggestion for sustainable value-creating activity points to the need for wider stakeholder participation in decision-making processes. In different parts of the world, certain groups and communities did not have a voice in activities related to agricultural recourses for decades. Such conditions do not conform to the new vision of value, and call for a change to accommodate a comprehensive representation of stakeholders.

\section{Conclusions}

This study presents a new sustainable value creation framework for the agricultural sector. This framework allows examination of an agricultural enterprise in different dimensions regarding its activities for creation of sustainable business value. Analysis of literature identified 23 factors reported to govern value creation by agricultural enterprises. These factors were aggregated into nine clusters: collaboration, knowledge, communication, production, diversification, entrepreneurism, funding, policies, and inclusiveness. Using these clusters of activities as a basis, a conceptual view on value creation in the context of the agricultural sector was developed. The overall conclusion from analysis of the literature was that the conceptualization of value in scientific articles is mostly one-dimensional, with a focus on financial benefits for enterprises, while disregarding the environmental and social aspects of TBL. The focus on financial benefits also involves a narrow stakeholder definition.

Re-thinking value creation in agricultural enterprises by considering all three aspects of TBL in balance is the way forward for future scientific work. This will mean questioning why value is created, for whom, the time perspective in which value is assessed, and the type of value given weight in the assessment. This will require the stakeholder definition to be widened to embrace the notion of shared value creation-something that other studies can explore. Future research should investigate business models that ensure collaboration, innovation, consumer inclusion, and knowledge transfer models for creating sustainable value. Longitudinal studies can be effective in investigating the change in enterprises that adopt a sustainable value paradigm. Finally, the linear perspective on value creation needs to be replaced with a circular perspective by focusing on the interaction between internal and external drivers for collaboration as part of a circular economy. Circularity offers a resource-based understanding of sustainable value creation using renewable resources and extending the use of non-renewable resources. Future research can benefit from a deeper understanding of how circularity contributes to value in a TBL perspective.

The results in this study have practical implications for managers and advisors in the agricultural sector, which corresponds to the recently published articles. For example, there is an indication that knowledge sharing allows for better managerial decisions for agricultural territory planning [161]; circular approach to agricultural residuals promise environmental benefits and financial gains [162]; and digital technology leads to enhanced value co-creation [163]. At the same time, many problems remain unsolved, such as lack of inclusiveness in global value chains $[164,165]$ or collaboration with farmers at the bottom of the pyramid [166].

This study provides comprehensive coverage of value-creating activities at farm level reported in the literature. It also suggests different activities that can move an agricultural enterprise towards sustainability in all three aspects of TBL. By adopting the new framework, advisors can communicate knowledge on sustainable value creation for agriculture through education and farmers can integrate sustainability into their value creating strategy. 
Author Contributions: Conceptualization, V.S., C.M.-H. and L.E.A.; methodology, V.S.; analysis of resources, V.S.; writing-original draft preparation, V.S., C.M.-H. and L.E.A.; writing-review and editing, V.S., C.M.-H. and L.E.A. All authors read and agreed on the published version of the manuscript.

Funding: The research was funded by Partnership Alnarp, SLU, Sweden.

Acknowledgments: The authors gratefully acknowledge financial support from SLU Partnership Alnarp and the support by the librarians at SLU Library. Thought-provoking comments by the anonymous reviewers notably contributed to the final version of this work.

Conflicts of Interest: The authors declare no conflict of interest. The funders had no influence on the design of the study, data collection and analysis, or on the manuscript writing and publishing.

\section{References}

1. Vargo, S.L.; Maglio, P.P.; Akaka, M.A. On value and value co-creation: A service systems and service logic perspective. Eur. Manag. J. 2008, 26, 145-152. [CrossRef]

2. Lepak, D.P.; Smith, K.G.; Taylor, M.S. Value Creation and Value Capture: A Multilevel Perspective. Acad. Manag. Rev. 2007, 32, 180-194. [CrossRef]

3. Brandenburger, A.M.; Stuart, H.W. Value-based Business Strategy. J. Econ. Manag. Strategy 1996, 5, 5-24. [CrossRef]

4. Peteraf, M.A.; Barney, J.B. Unraveling the resource-based tangle. Manag. Decis. Econ. 2003, 24, $309-323$. [CrossRef]

5. Helfat, C.E.; Finkelstein, S.; Mitchell, W.; Peteraf, M.; Singh, H.; Teece, D.; Winter, S.G. Dynamic Capabilities: Understanding Strategic Change in Organizations; John Wiley \& Sons: Hoboken, NJ, USA, 2009; ISBN 978-1-4051-8206-5.

6. Teece, D.J. Profiting from technological innovation: Implications for integration, collaboration, licensing and public policy. Res. Policy 1986, 15, 285-305. [CrossRef]

7. Brandenburger, A.M.; Nalebuff, B. The Right Game: Use Game Theory to Shape Strategy. Available online: https://hbr.org/1995/07/the-right-game-use-game-theory-to-shape-strategy (accessed on 3 January 2018).

8. Christos, N. Pitelis The Co-Evolution of Organizational Value Capture, Value Creation and Sustainable Advantage. Organ. Stud. 2009, 30, 1115-1139. [CrossRef]

9. Rainey, D.L. Sustainable Business Development: Inventing the Future Through Strategy, Innovation, and Leadership; Cambridge University Press: Cambridge, UK, 2006.

10. Elkington, J. Cannibals with Forks: The Triple Bottom Line of 21st Century Business; New Society Publishers: Gabriola, BC, Canada, 1998; ISBN 978-0-86571-392-5.

11. World Economic Forum Innovation with a Purpose: Strengthening Food Systems through Technology. Available online: https://www.weforum.org/projects/innovation-with-a-purpose-strengthening-foodsystems-through-technology (accessed on 17 June 2020).

12. Hart, S.L.; Milstein, M.B. Creating sustainable value. Acad. Manag. Exec. 2003, 17, 56-67. [CrossRef]

13. Jensen, P.A. The Facilities Management Value Map: A conceptual framework. Facilities 2010, 28, $175-188$. [CrossRef]

14. Bowman, C.; Ambrosini, V. Value Creation Versus Value Capture: Towards a Coherent Definition of Value in Strategy. Br. J. Manag. 2000, 11, 1-15. [CrossRef]

15. Priem, R.L. A Consumer Perspective on Value Creation. Acad. Manag. Rev. 2007, 32, 219-235. [CrossRef]

16. Sirmon, D.G.; Hitt, M.A.; Ireland, R.D. Managing Firm Resources in Dynamic Environments to Create Value: Looking Inside the Black Box. Acad. Manag. Rev. 2007, 32, 273-292. [CrossRef]

17. Porter, M.E. Competitive Strategy: Techniques for Analyzing Industries and Competitors; Free Press: New York, NY, USA, 1980.

18. Kordupleski, R. Mastering Customer Value Management: The Art and Science of Creating Competitive Advantage; Pinnaflex Educational Resources Inc.: Columbus, OH, USA, 2003; ISBN 978-1-893673-07-6.

19. Steurer, R.; Langer, M.E.; Konrad, A.; Martinuzzi, A. Corporations, Stakeholders and Sustainable Development I: A Theoretical Exploration of Business-Society Relations. J. Bus. Ethics 2005, 61, 263-281. [CrossRef]

20. Dyllick, T.; Hockerts, K. Beyond the business case for corporate sustainability. Bus. Strategy Environ. 2002, 11, 130-141. [CrossRef] 
21. Gladwin, T.N.; Kennelly, J.J.; Krause, T.-S. Shifting paradigms for sustainable development: Implications for management theory and research. Acad. Manag. Rev. 1995, 20, 874-907. [CrossRef]

22. Porter, M.E.; Kramer, M.R. Creating Shared Value. In Managing Sustainable Business: An Executive Education Case and Textbook; Lenssen, G.G., Smith, N.C., Eds.; Springer: Dordrecht, The Netherlands, 2019; pp. 323-346. ISBN 978-94-024-1144-7.

23. Morioka, S.N.; Bolis, I.; Carvalho, M.M.D. From an ideal dream towards reality analysis: Proposing Sustainable Value Exchange Matrix (SVEM) from systematic literature review on sustainable business models and face validation. J. Clean. Prod. 2018, 178, 76-88. [CrossRef]

24. Coltrain, D.; Barton, D.; Boland, M. Value Added: Opportunities and Strategies; Arthur Capper Cooperative, Center Department of Agricultural Economics, Cooperative Extension Service, Kansas State University: Manhattan, KS, USA, 2000.

25. Womach, J. Agriculture: A Glossary of Terms, Programs, and Laws, 2005 Edition. Available online: https://digital.library.unt.edu/ark:/67531/metacrs7246/ (accessed on 10 January 2018).

26. Amanor-Boadu, V.A. Conversation about Value-Added Agriculture; Value-Added Business Development Program; Department of Agricultural Economics; Kansas State University: Manhattan, KS, USA, 2003.

27. Ernst and Woods Adding Value to Plant Production: An Overview. Available online: http://www.uky.edu/ ccd/marketing/market-resources/v-a/overview (accessed on 10 January 2018).

28. Lu, R.; Dudensing, R. What Do We Mean by Value-added Agriculture? Choices 2015, 30, 316-2016-7795.

29. USDA Value Added Producer Grants | USDA Rural Development. Available online: https://www.govinfo. gov/content/pkg/FR-2015-05-08/pdf/2015-10441.pdf (accessed on 28 September 2019).

30. Rowley, J.; Slack, F. Conducting a literature review. Manag. Res. News 2004, 27, 31-39. [CrossRef]

31. Tranfield, D.; Denyer, D.; Smart, P. Towards a Methodology for Developing Evidence-Informed Management Knowledge by Means of Systematic Review. Br. J. Manag. 2003, 14, 207-222. [CrossRef]

32. Seuring, S.; Müller, M. From a literature review to a conceptual framework for sustainable supply chain management. J. Clean. Prod. 2008, 16, 1699-1710. [CrossRef]

33. Moher, D.; Shamseer, L.; Clarke, M.; Ghersi, D.; Liberati, A.; Petticrew, M.; Shekelle, P.; Stewart, L.A. PRISMA-P Group Preferred reporting items for systematic review and meta-analysis protocols (PRISMA-P) 2015 statement. Syst. Rev. 2015, 4, 1. [CrossRef]

34. Bandara, W.; Miskon, S.; Fielt, E. A systematic, tool-supported method for conducting literature reviews in information systems. In Proceedings of the Proceedings of the 19th European Conference on Information Systems (ECIS 2011), Helsinki, Finland, 9-11 June 2011.

35. Laplume, A.O.; Sonpar, K.; Litz, R.A. Stakeholder theory: Reviewing a theory that moves us. J. Manag. 2008, 34, 1152-1189. [CrossRef]

36. Eastwood, C.R.; Chapman, D.F.; Paine, M.S. Networks of practice for co-construction of agricultural decision support systems: Case studies of precision dairy farms in Australia. Agric. Syst. 2012, 108, 10-18. [CrossRef]

37. Nettle, R.; Brightling, P.; Hope, A. How Programme Teams Progress Agricultural Innovation in the Australian Dairy Industry. J. Agric. Educ. Ext. 2013, 19, 271-290. [CrossRef]

38. Thilmany, D.D.; Umberger, W.J.; Ziehl, A.R. Strategic market planning for value-added natural beef products: A cluster analysis of Colorado consumers. Renew. Agric. Food Syst. 2006, 21, 192-203. [CrossRef]

39. Armstrong, G.; Farley, H.; Gray, J.; Durkin, M. Marketing health-enhancing foods: Implications from the dairy sector. Mark. Intell. Plan. 2005, 23, 705-719. [CrossRef]

40. Higgins, A.J.; Laredo, L.A. Improving Harvesting and Transport Planning within a Sugar Value Chain. J. Oper. Res. Soc. 2006, 57, 367-376. [CrossRef]

41. Sogn-Grundvag, G.; Larsen, T.A.; Young, J.A. Product differentiation with credence attributes and private labels: The case of whitefish in UK supermarkets. J. Agric. Econ. 2014, 65, 368-382. [CrossRef]

42. Deselnicu, O.C.; Costanigro, M.; Souza-Monteiro, D.M.; McFadden, D.T. A Meta-Analysis of Geographical Indication Food Valuation Studies: What Drives the Premium for Origin-Based Labels? J. Agric. Resour. Econ. 2013, 38 .

43. Anic, I.-D.; Nusinovic, M. The apple industry in Croatia: A value chain analysis approach. Int. J. Entrep. Small Bus. 2005, 2, 211-225. [CrossRef]

44. Atănăsoaie, G. Distribution channels on the organic foods market. J. Hortic. For. Biotechnol. 2011, 15, 19-25.

45. Austin, J.E.; Leonard, H.B. Can the virtuous mouse and the wealthy elephant live happily ever after? Calif. Manag. Rev. 2008, 51,77-102. [CrossRef] 
46. Badar, H.; Ariyawardana, A.; Collins, R. Capturing Consumer Preferences for Value Chain Improvements in the Mango Industry of Pakistan. Available online: https://ageconsearch.umn.edu/record/208498 (accessed on 13 January 2019).

47. Baron, D.P. Credence attributes, voluntary organizations, and social pressure. J. Public Econ. 2011, 95, 1331-1338. [CrossRef]

48. Batterink, M.H.; Wubben, E.F.M.; Klerkx, L.; Omta, S.W.F. (Onno) Orchestrating innovation networks: The case of innovation brokers in the agri-food sector. Entrep. Reg. Dev. 2010, 22, 47-76. [CrossRef]

49. Bertazzoli, A.; Fiorini, A.; Ghelfi, R.; Rivaroli, S.; Samoggia, A.; Mazzotti, V. Food Chains and Value System: The Case of Potato, Fruit, and Cheese. J. Food Prod. Mark. 2011, 17, 303-326. [CrossRef]

50. Boehlje, M. Business challenges in commercialization of agricultural technology. Int. Food Agribus. Manag. Rev. 2004, 7, 91.

51. Bogale, S.A.; Verhees, F.J.; Trijp, H.C. van Customer Evaluation of Supply Systems: The Case of Ethiopian Seed Supply Systems. J. Afr. Bus. 2018, 19, 550-570. [CrossRef]

52. Boland, M.A. Cargill: Biotechnology and Value Creation in Wheat. Available online: https://ageconsearch. umn.edu/record/34397 (accessed on 14 January 2019).

53. Bongiovanni, R.; Lowenberg-Deboer, J. Precision Agriculture and Sustainability. Precis. Agric. 2004, 5, 359-387. [CrossRef]

54. Bonney, L.; Collins, R.; Miles, M.P.; Verreynne, M.-L. A note on entrepreneurship as an alternative logic to address food security in the developing world. J. Dev. Entrep. 2013, 18, 1350016. [CrossRef]

55. Bramley, C.; Kirsten, J.F. Exploring the economic rationale for protecting geographical indicators in agriculture. Agrekon 2007, 46, 69-93. [CrossRef]

56. Briscoe, R.; Ward, M. In Small Both Beautiful and Competitive? A Case Study of Irish Dairy Cooperatives. J. Rural Coop. 2006, 34, 119-138.

57. Bryla, P. Creating and Delivering Value for Consumers of Healthy Food-a Case Study of Organic Farma Zdrowia SA. J. Manag. Bus. Adm. Cent. Eur. 2017, 25, 55-74.

58. Campbell, D.; Doherty, E. Combining discrete and continuous mixing distributions to identify niche markets for food. Eur. Rev. Agric. Econ. 2013, 40, 287-312. [CrossRef]

59. Carriquiry, M.; Babcock, B.A. Reputations, market structure, and the choice of quality assurance systems in the food industry. Am. J. Agric. Econ. 2007, 89, 12-23. [CrossRef]

60. Che, D. Developing ecotourism in First World, resource-dependent areas. Geoforum 2006, 37, $212-226$. [CrossRef]

61. Chen, Y.-J.; Tang, C.S. The Economic Value of Market Information for Farmers in Developing Economies. Prod. Oper. Manag. 2015, 24, 1441-1452. [CrossRef]

62. Chumaidiyah, E. Value Chain Map of Small Agricultural Product-Processing Enterprises in Bandung, Indonesia. Int. J. Supply Chain Manag. 2017, 6, 76-82.

63. Cloesen, U. Entrepreneurship within rural tourism: A private walkway on Banks Peninsula, New Zealand. Turiz. Med. Junarodni Znan. Stručni Časopis 2007, 55, 81-91.

64. Cucagna, M.E.; Goldsmith, P.D. Value adding in the agri-food value chain. Int. Food Agribus. Manag. Rev. 2018, 21, 293-316. [CrossRef]

65. Darroch, M.A.; Akridge, J.T.; Boehlje, M.D. Capturing value in the supply chain: The case of high oleic acid soybeans. Int. Food Agribus. Manag. Rev. 2002, 5, 87-103. [CrossRef]

66. Dentoni, D.; Hospes, O.; Ross, R.B. Managing wicked problems in agribusiness: The role of multi-stakeholder engagements in value creation: Editor's Introduction. Int. Food Agribus. Manag. Rev. 2012, 15, 1-12.

67. De Carvalho, B.R.P.; Mendes, H. Cashew Chain Value in Guiné-Bissau: Challenges and Contributions for Food Security: A Case Study for Guiné-Bissau. Int. J. Food Syst. Dyn. 2016, 7, 1-13.

68. Declerck, F.; Cloutier, L.M. The financial value of corporations in a cobweb economy: Champagne industry dynamics. Int. J. Wine Bus. Res. 2010, 22, 269-287. [CrossRef]

69. Dey, B.L.; Pandit, A.; Saren, M.; Bhowmick, S.; Woodruffe-Burton, H. Co-creation of value at the bottom of the pyramid: Analysing Bangladeshi farmers' use of mobile telephony. J. Retail. Consum. Serv. 2016, 29, 40-48. [CrossRef]

70. Di Gregorio, D. Place-based business models for resilient local economies: Cases from Italian slow food, agritourism and the albergo diffuso. J. Enterp. Communities People Places Glob. Econ. 2017, 11, 113-128. [CrossRef] 
71. Duffy, R.; Fearne, A. Buyer-Supplier Relationships: An Investigation of Moderating Factors on the Development of Partnership Characteristics and Performance. Available online: https://ageconsearch. umn.edu/record/8116 (accessed on 13 January 2019).

72. Fafchamps, M.; Minten, B. Returns to social network capital among traders. Oxf. Econ. Pap. 2002, 54, $173-206$. [CrossRef]

73. Ferraz, L.Z.T.; Rezende, A.J.; Lima, J.P.R.D.; Todeva, E. Perception of Value Co-creation Actions in Agricultural Cooperatives. Braz. Adm. Rev. 2018, 15. [CrossRef]

74. Giannakis, E.; Bruggeman, A. The highly variable economic performance of European agriculture. Land Use Policy 2015, 45, 26-35. [CrossRef]

75. Gloy, B.A.; Akridge, J.T. Computer and internet adoption on large US farms. Int. Food Agribus. Manag. Rev. 2000, 3, 323-338. [CrossRef]

76. Gray, A.; Boehlje, M.; Amanor-Boadu, V.; Fulton, J. Agricultural Innovation and New Ventures: Assessing the Commercial Potential. Am. J. Agric. Econ. 2004, 86, 1322-1329. [CrossRef]

77. Goldsmith, P.; Bender, K. Ten conversations about identity preservation. J. Chain Netw. Sci. 2004, 4, 111-123. [CrossRef]

78. Goldsmith, P.; Gow, H. Strategic Positioning Under Agricultural Structural Change: A Critique of Long Jump Co-operative Ventures. Int. Food Agribus. Manag. Rev. 2005, 8, 22.

79. Grunert, K.G.; Jeppesen, L.F.; Jespersen, K.R.; Sonne, A.-M.; Hansen, K.; Trondsen, T.; Young, J.A. Market orientation of value chains: A conceptual framework based on four case studies from the food industry. Eur. J. Mark. 2005, 39, 428-455. [CrossRef]

80. Hall, A. Capacity development for agricultural biotechnology in developing countries: An innovation systems view of what it is and how to develop it. J. Int. Dev. 2005, 17, 611-630. [CrossRef]

81. Hsu, S.-M.; Hsieh, P.-H.; Yuan, S.-T. Roles of 'small- and medium-sized enterprises' in service industry innovation: A case study on leisure agriculture service in tourism regional innovation. Serv. Ind. J. 2013, 33, 1068-1088. [CrossRef]

82. Han, I.; Chuang, C.-M. The antecedents and consequences of local embeddedness: A framework based on the rice industry in Taiwan. Asian Bus. Manag. 2015, 14, 195-226. [CrossRef]

83. Handayati, Y.; Simatupang, T.M.; Perdana, T. Agri-food supply chain coordination: The state-of-the-art and recent developments. Logist. Res. 2015, 8, 5. [CrossRef]

84. Hartlieb, S.; Jones, B. Humanising Business Through Ethical Labelling: Progress and Paradoxes in the UK. J. Bus. Ethics 2009, 88, 583-600. [CrossRef]

85. Hastings, K.; Howieson, J.; Lawley, M. Creating value chains: The role of relationship development. Br. Food J. 2016, 118, 1384-1406. [CrossRef]

86. Hinrichs, C.C. Embeddedness and local food systems: Notes on two types of direct agricultural market. J. Rural. Stud. 2000, 16, 295-303. [CrossRef]

87. Hinterhuber, A. Value chain orchestration in action and the case of the global agrochemical industry. Long Range Plan. 2002, 35, 615-635. [CrossRef]

88. Howieson, J.; Lawley, M.; Hastings, K. Value chain analysis: An iterative and relational approach for agri-food chains. Supply Chain Manag. Int. J. 2016, 21, 352-362. [CrossRef]

89. Hunt, D.M.; Geiger-Oneto, S.; Varca, P.E. Satisfaction in the context of customer co-production: A behavioral involvement perspective. J. Consum. Behav. 2012, 11, 347-356. [CrossRef]

90. Jayashankar, P.; Nilakanta, S.; Johnston, W.J.; Gill, P.; Burres, R. IoT adoption in agriculture: The role of trust, perceived value and risk. J. Bus. Ind. Mark. 2018, 33, 804-821. [CrossRef]

91. Jayashankar, P.; Van Auken, H.; Ashta, A. What motivates ecopreneurs in the United States to create value? Strateg. Chang 2018, 27, 509-521. [CrossRef]

92. Jraisat, L. A network perspective and value added tasks: The case of agri-food value chain. Asia Pac. J. Mark. Logist. 2016, 28, 350-365. [CrossRef]

93. Jolink, A.; Niesten, E. Sustainable development and business models of entrepreneurs in the organic food industry. Bus. Strategy Environ. 2015, 24, 386-401. [CrossRef]

94. Kaaristo, M. Value of silence: Mediating aural environments in Estonian rural tourism. J. Tour. Cult. Chang 2014, 12, 267-279. [CrossRef]

95. Kastelli, I.; Tsakanikas, A.; Caloghirou, Y. Technology transfer as a mechanism for dynamic transformation in the food sector. J. Technol. Transf. 2018, 43, 882-900. [CrossRef] 
96. Katz, J.P.; Boland, M.A. One for All and All for One? A New Generation of Co-operatives Emerges. Long Range Plan. 2002, 35, 73-89. [CrossRef]

97. Kline, C.; Boluk, K.; Shah, N.M. Exploring social entrepreneurship in food tourism. In Social Entrepreneurship and Tourism; Springer: Berlin, Germany, 2017; pp. 135-154.

98. Leguizamon, F.; Selva, G.; Santos, M. Small farmer suppliers from local to global. J. Bus. Res. 2016, 69, 4520-4525. [CrossRef]

99. Liang, A.R.-D. Considering the role of agritourism co-creation from a service-dominant logic perspective. Tour. Manag. 2017, 61, 354-367. [CrossRef]

100. London, T.; Anupindi, R.; Sheth, S. Creating mutual value: Lessons learned from ventures serving base of the pyramid producers. J. Bus. Res. 2010, 63, 582-594. [CrossRef]

101. Lutkemeyer Filho, M.G.; RoeheVaccaro, G.L.; Freitas, E.C. de Identification of customer satisfaction in services: A study on agribusiness dealers. Rev. Bras. Gest. Neg. 2015, 17, 1408-1425.

102. Marotta, G.; Nazzaro, C.; Stanco, M. How the social responsibility creates value: Models of innovation in Italian pasta industry. Int. J. Glob. Small Bus. 2017, 9, 144-167. [CrossRef]

103. Matopoulos, A.; Vlachopoulou, M.; Manthou, V.; Manos, B. A conceptual framework for supply chain collaboration: Empirical evidence from the agri-food industry. Supply Chain Manag. Int. J. 2007, 12, 177-186. [CrossRef]

104. McBratney, A.; Whelan, B.; Ancev, T.; Bouma, J. Future Directions of Precision Agriculture. Precis. Agric. 2005, 6, 7-23. [CrossRef]

105. Melton, B.E.; Huffman, W.E. Beef and Pork Packing Costs and Input Demands: Effects of Unionization and Technology. Am. J. Agric. Econ. 1995, 77, 471-485. [CrossRef]

106. Mishra, A.; Wilson, C.; Williams, R. Factors affecting financial performance of new and beginning farmers. Agric. Financ. Rev. 2009, 69, 160-179. [CrossRef]

107. Moeen, M.; Agarwal, R. Incubation of an industry: Heterogeneous knowledge bases and modes of value capture. Strateg. Manag. J. 2017, 38, 566-587. [CrossRef]

108. Menozzi, D. Extra-virgin olive oil production sustainability in northern Italy: A preliminary study. Br. Food J. 2014, 116, 1942-1959. [CrossRef]

109. Meissner, F.; Komba, X.K. Balanced growth through local entrepreneurship: The Komba coffee project in southern Tanzania. In Balanced Growth; Springer: Berlin, Germany, 2012; pp. 183-193.

110. MK Leat, P.; Revoredo-Giha, C. In search of differentiation and the creation of value: The quest of the Scottish pig supply chain. Br. Food J. 2013, 115, 1487-1504. [CrossRef]

111. Migliore, G.; Schifani, G.; Cembalo, L. Opening the black box of food quality in the short supply chain: Effects of conventions of quality on consumer choice. Food Qual. Prefer. 2015, 39, 141-146. [CrossRef]

112. Micheels, E.T.; Gow, H.R. Do market oriented firms demonstrate clarity on their value discipline? Evidence from Illinois beef producers. Int. Food Agribus. Manag. Rev. 2009, 12, 127.

113. Montealegre, F.; Thompson, S.R.; Eales, J.S. An Empirical Analysis of the Determinants of Success of Food and Agribusiness E-Commerce Firms. Available online: https://ageconsearch.umn.edu/record/8168 (accessed on 13 January 2019).

114. Moulton, K.S.; Zwane, A.P. Managing Environmental Risks through Private Sector Cooperation: Cooperation: Theory, Experience and a Case Study of the California Code of Sustainable Winegrowing Practices. Available online: https://ageconsearch.umn.edu/record/8131 (accessed on 13 January 2019).

115. Munjal, S.; Sharma, S.; Menon, P. Moving towards "Slow Food", the new frontier of culinary innovation in India: The Vedatya experience. Worldw. Hosp. Tour. Themes 2016, 8, 444-460. [CrossRef]

116. Neganova, I.S. Managing core competences to create value for customers. World Rev. Entrep. Manag. Sustain. Dev. 2010, 6, 304-317. [CrossRef]

117. Pannekoek, L.; van Kooten, O.; Kemp, R.; Omta, S. Entrepreneurial innovation in chains and networks in Dutch greenhouse horticulture. J. Chain Netw. Sci. 2005, 5, 39-50. [CrossRef]

118. Pant, L.P.; Hambly-Odame, H.; Hall, A.; V, R.S. Beyond the supply chains of technology and commodity: Challenges to strengthening mango innovation systems in Andhra Pradesh, India. World J. Sci. Technol. Sustain. Dev. 2012, 9, 175-193. [CrossRef]

119. Pascucci, S.; Magistris, T. de Information Bias Condemning Radical Food Innovators? The Case of Insect-Based Products in the Netherlands. Available online: https://ageconsearch.umn.edu/record/156421 (accessed on 13 June 2019). 
120. Patel, D.M. The Export Trading Group: Unlocking Africa's Agricultural Potential. Int. Food Agribus. Manag. Rev. 2014, 17, 187.

121. Pennings, J. Commodity futures markets as drivers of agriculture and agribusinesses in developing countries: What needs to be done? Mark. Mark. 2010.

122. Peterson, H.C. Fundamental Principles of Managing Multi-Stakeholder Engagement. Available online: https://ageconsearch.umn.edu/record/155141 (accessed on 13 June 2019).

123. Polo Redondo, Y.; Cambra Fierro, J.J. Importance of company size in long-term orientation of supply function: An empirical research. J. Bus. Ind. Mark. 2007, 22, 236-248. [CrossRef]

124. Poniman, D.; Purchase, S.; Sneddon, J. Traceability systems in the Western Australia halal food supply chain. Asia Pac. J. Mark. Logist. 2015, 27, 324-348. [CrossRef]

125. Ramesh, G. Mainstreaming an unorganized industry: The case of Suguna poultry. Vikalpa 2010, 35, 35-48. [CrossRef]

126. Ruslan, N.A.; Man, N.; Nawi, N.M.; Ding, P. Factors That Influence the Implementation of Postharvest Handling Practices Among Fresh Vegetable Producers in Selected States in Malaysia. J. Int. Food Agribus. Mark. 2013, 25, 87-97. [CrossRef]

127. Safri, M. Mapping noncapitalist supply chains: Toward an alternate conception of value creation and distribution. Organization 2015, 22, 924-941. [CrossRef]

128. Shah, S.; Ghazzawi, I.A. Bc Frozen Foods Limited: Challenges and Change1. J. Int. Acad. Case Stud. 2012, 18,1 .

129. Semenda, D.K.; Semenda, O.V.; Gvozdiei, N.I. ANALYSIS OF TAX ENVIRONMENT OF BUSINESS IN AGRARIAN SECTOR OF ECONOMY OF UKRAINE. Financ. Credit Act. Probl. Theory Pract. 2018, 2, 148-156. [CrossRef]

130. Sexton, R.J.; Sheldon, I.; McCorriston, S.; Wang, H. Agricultural trade liberalization and economic development: The role of downstream market power. Agric. Econ. 2007, 36, 253-270. [CrossRef]

131. Shieh, C.-J.; Hu, R. Evaluating business performance of agricultural cooperation groups with Data Envelopment Analysis. Custos E Agronegocio 2016, 12, 2-16.

132. Sturaro, E.; Marchiori, E.; Cocca, G.; Penasa, M.; Ramanzin, M.; Bittante, G. Dairy systems in mountainous areas: Farm animal biodiversity, milk production and destination, and land use. Livest. Sci. 2013, 158, 157-168. [CrossRef]

133. Sturiale, L.; Scuderi, A. The digital economy: New e-business strategies for food Italian system. Int. J. Electron. Mark. Retail. 2016, 7, 287-310. [CrossRef]

134. Starr, A.; Card, A.; Benepe, C.; Auld, G.; Lamm, D.; Smith, K.; Wilken, K. Sustaining local agriculture Barriers and opportunities to direct marketing between farms and restaurants in Colorado. Agric. Hum. Values 2003, 20, 301-321. [CrossRef]

135. Tampe, M. Leveraging the Vertical: The Contested Dynamics of Sustainability Standards and Labour in Global Production Networks. Br. J. Ind. Relat. 2018, 56, 43-74. [CrossRef]

136. Tang, C.S.; Sodhi, M.S.; Formentini, M. An analysis of partially-guaranteed-price contracts between farmers and agri-food companies. Eur. J. Oper. Res. 2016, 254, 1063-1073. [CrossRef]

137. Teklehaimanot, M.L.; Ingenbleek, P.T.M.; Trijp, H.C.M. van The Transformation of African Smallholders into Customer Value Creating Businesses: A Conceptual Framework. J. Afr. Bus. 2017, 18, 299-319. [CrossRef]

138. Tencati, A.; Zsolnai, L. Collaborative enterprise and sustainability: The case of slow food. J. Bus. Ethics 2012, 110, 345-354. [CrossRef]

139. Thomas-Francois, K.; Joppe, M.; von Massow, M. Improving linkages through a service-oriented Local farmers-hotel supply chain-An Explanatory case in Grenada. Tour. Plan. Dev. 2018, 15, 398-418. [CrossRef]

140. Tzouramani, I.; Sintori, A.; Liontakis, A.; Karanikolas, P.; Alexopoulos, G. An assessment of the economic performance of organic dairy sheep farming in Greece. Livest. Sci. 2011, 141, 136-142. [CrossRef]

141. Uzea, F.N.; Fulton, M.E. Mechanisms for effective alliance management: Insights from a federated cooperative marketing system. Int. Food Agribus. Manag. Rev. 2014, 17, 95.

142. Woiceshyn, J. Lessons in product innovation: A case study of biotechnology firms. RD Manag. 1995, 25, 395-409. [CrossRef]

143. Zavorotin, E.F.; Yurkova, M.S.; Serdobintsev, D.V.; Likhovtsova, E.A.; Voloshchuk, L.A. Perfecting the Cluster Development in the Regional Dairy Products Subcomplex of the Russian Agro-Industrial Complex. J. Environ. Manag. Tour. 2018, 9, 947-954. [CrossRef] 
144. Pusporini, P.; Abhary, K.; Luong, L. Intelligent Design of Environmental Performance Evaluation Using Fuzzy Expert System; Trans Tech Publications Ltd.: Stafa-Zurich, Switzerland, 2013; Volume 330.

145. Gebbers, R.; Adamchuk, V.I. Precision Agriculture and Food Security. Science 2010, 327, 828-831. [CrossRef] [PubMed]

146. Tóth, J.; Migliore, G.; Schifani, G.; Rizzo, G. Sustainable Value Creation in the Food Chain: A Consumer Perspective. Sustainability 2020, 12, 1438. [CrossRef]

147. Nogueira, A.; Ashton, W.; Teixeira, C.; Lyon, E.; Pereira, J. Infrastructuring the Circular Economy. Energies 2020, 13, 1805. [CrossRef]

148. Donner, M.; Gohier, R.; de Vries, H. A new circular business model typology for creating value from agro-waste. Sci. Total Environ. 2020, 716, 137065. [CrossRef] [PubMed]

149. Shen, N. Customer Knowledge Sharing Incentive Mechanism in Agricultural Products Supply Chain in Big Data Context. Rev. Fac. Agron. Univ. Zulia 2019.

150. Nazzaro, C.; Stanco, M.; Marotta, G. The Life Cycle of Corporate Social Responsibility in Agri-Food: Value Creation Models. Sustainability 2020, 12, 1287. [CrossRef]

151. Mendelsohn, R.; Nordhaus, W.; Shaw, D. Climate impacts on aggregate farm value: Accounting for adaptation. Agric. For. Meteorol. 1996, 80, 55-66. [CrossRef]

152. Ao, X.H.; Vu, T.V.; Le, K.D.; Jirakiattikul, S.; Techato, K. An analysis of the smallholder farmers' cassava (Manihot esculenta Crantz) value chain through a gender perspective: The case of Dak Lak province, Vietnam. Cogent Econ. Finance 2019, 7, 1645632. [CrossRef]

153. Dumont, E.S.; Bonhomme, S.; Pagella, T.F.; Sinclair, F.L. Structured stakeholder engagement leads to development of more diverse and inclusive agroforestry options. Exp. Agric. 2019, 55, 252-274. [CrossRef]

154. Hall, J.K.; Martin, M.J.C. Disruptive technologies, stakeholders and the innovation value-added chain: A framework for evaluating radical technology development. RD Manag. 2005, 35, 273-284. [CrossRef]

155. Baumgartner, R.J.; Korhonen, J. Strategic thinking for sustainable development. Sustain. Dev. 2010, 18, 71-75. [CrossRef]

156. Shennan, C. Biotic interactions, ecological knowledge and agriculture. Philos. Trans. R. Soc. B Biol. Sci. 2008, 363, 717-739. [CrossRef] [PubMed]

157. Knight, J.; Weir, S.; Woldehanna, T. The role of education in facilitating risk-taking and innovation in agriculture. J. Dev. Stud. 2003, 39, 1-22. [CrossRef]

158. Hult, G.T.M.; Hurley, R.F.; Knight, G.A. Innovativeness: Its antecedents and impact on business performance. Ind. Mark. Manag. 2004, 33, 429-438. [CrossRef]

159. Ellen MacArthur Foundation. Circular Economy Report-Towards the Circular Economy; Ellen MacArthur Foundation: Cowes, UK, 2014; Volume 3.

160. European Commission Bioeconomy. Available online: https://ec.europa.eu/programmes/horizon2020/en/ h2020-section/bioeconomy (accessed on 29 March 2020).

161. Maizza, A.; Fait, M.; Scorrano, P.; Iazzi, A. How Knowledge Sharing Culture Can Become a Facilitator of the Sustainable Development in the Agrifood Sector. Sustainability 2019, 11, 952. [CrossRef]

162. Dyjakon, A.; García-Galindo, D. Implementing Agricultural Pruning to Energy in Europe: Technical, Economic and Implementation Potentials. Energies 2019, 12, 1513. [CrossRef]

163. Jayashankar, P.; Johnston, W.J.; Nilakanta, S.; Burres, R. Co-creation of value-in-use through big data technology-A B2B agricultural perspective. J. Bus. Ind. Mark. 2019, 35, 508-523. [CrossRef]

164. Grabs, J.; Ponte, S. The evolution of power in the global coffee value chain and production network. J. Econ. Geogr. 2019, 19, 803-828. [CrossRef]

165. Chamberlain, W.O.; Anseeuw, W. Inclusiveness revisited: Assessing inclusive businesses in South African agriculture. Dev. S. Afr. 2019, 36, 600-615. [CrossRef]

166. Hernandez-Cazares, R.; Lawson-Lartego, L.; Mathiassen, L.; Quinonez-Romandia, S. Strategizing for the bottom of the pyramid: An action research into a Mexican agribusiness. J. Bus. Ind. Mark. 2019. [CrossRef]

(C) 2020 by the authors. Licensee MDPI, Basel, Switzerland. This article is an open access article distributed under the terms and conditions of the Creative Commons Attribution (CC BY) license (http://creativecommons.org/licenses/by/4.0/). 